\title{
Dipsas sazimai Fernandes, Marques \& Argolo, 2010 (Squamata: Dipsadidae): Distribution extension and new State record
}

\author{
Igor Joventino Roberto*, Cícero Ricardo de Oliveira, João Antonio de Araujo Filho and Robson \\ Waldemar Ávila \\ 1 Universidade Regional do Cariri, Centro de Ciências Biológicas e da Saúde, Departamento de Ciências Biológicas, Campus do Pimenta. Rua Cel. \\ Antonio Luiz, 1161, Bairro do Pimenta, CEP 63105-100, Crato, CE, Brazil. \\ * Corresponding author. E-mail: igorjoventino@yahoo.com.br
}

\begin{abstract}
We provide the first record of Dipsas sazimai for the state of Pernambuco, at RPPN Pedra D'Antas, municipality of Jaqueira, extending the known distribution in $73 \mathrm{~km}$ north from the closest locality, municipality of Murici, state of Alagoas. The discovery of a new population of this rare snake reinforces the need of conservation of the reminiscent Atlantic forest of the Pernambuco Endemism Center.
\end{abstract}

The Atlantic Forest north to the São Francisco River presents two biogeographic units: the low land forests in the coastal zone and the highland marshes ("Brejos de Altitude") (Tabarelli et al. 2005). The Pernambuco Endemism Center is one of the biogeographical sub-units of this region (sensu Silva and Casteleti 2003). Despite its high biodiversity, only $2 \%$ of the original pristine forest remains, and the small forest fragments are considered as key target for biological conservation (Asfora and Pontes 2009; Ribeiro et al. 2009).

The snake Dipsas sazimai is characterized by the presence of rounded dorsal blotches wider than interblotches; posterior body blotches lighter than anterior blotches, with conspicuous white edge in paraventral region; tiny and vertically oriented streaks in the interblotches from the posterior half of the body, 187-209 ventral scales; 107-129 caudal scales (Fernandes et al. 2010). This species is endemic to the Atlantic Forest in Brazil, occurring in the states of Rio de Janeiro, São Paulo, Espírito Santo, Bahia and Alagoas, from elevations of 0 to $700 \mathrm{~m}$ (Fernandes et al. 2010).

During a herpetofauna monitoring project in the Atlantic Forest of the Pernambuco Endemism Center, at the Private Protected Area of RPPN Pedra D'Antas (Figure 1A), municipality of Jaqueira, Serra do Urubu

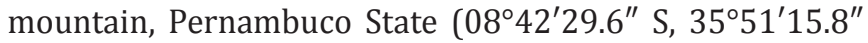
W, 702 a.s.l.m), Brazil, we collected an adult individual of Dipsas sazimai (SVL $38.6 \mathrm{~cm}$, TL $18.2 \mathrm{~cm}$ ), housed in the herpetological collection of Universidade Regional do Cariri (URCA-H 5097) (Figure 1B), coiled in a branch at $1.40 \mathrm{~m}$ of height, on March 12 of 2013, 20:23 h (permits: 34734-1).

This is the first record of $D$. sazimai for the Pernambuco State (Figure 2), and the second record for the Pernambuco Endemism Center, extending the known distribution 73 $\mathrm{km}$ north from the closest locality, the municipality of Murici, state of Alagoas (Fernandes et al. 2010).

Despite our specimen fits with the diagnostic characters described in Fernandes et al. (2010), there is a huge variation in color pattern in live. The live specimen in the original description (IBSP 77835) have a creamy ground color with black blotches and dark brown iris, whereas our specimen have a reddish brown ground color with dark brown blotches and silver iris (Figure 1B). The specimen depicted in Hamdan and Lira-da-Silva (2012) also has a reddish brown ground color, but have a dark brown iris. Morphological analysis of additional specimens

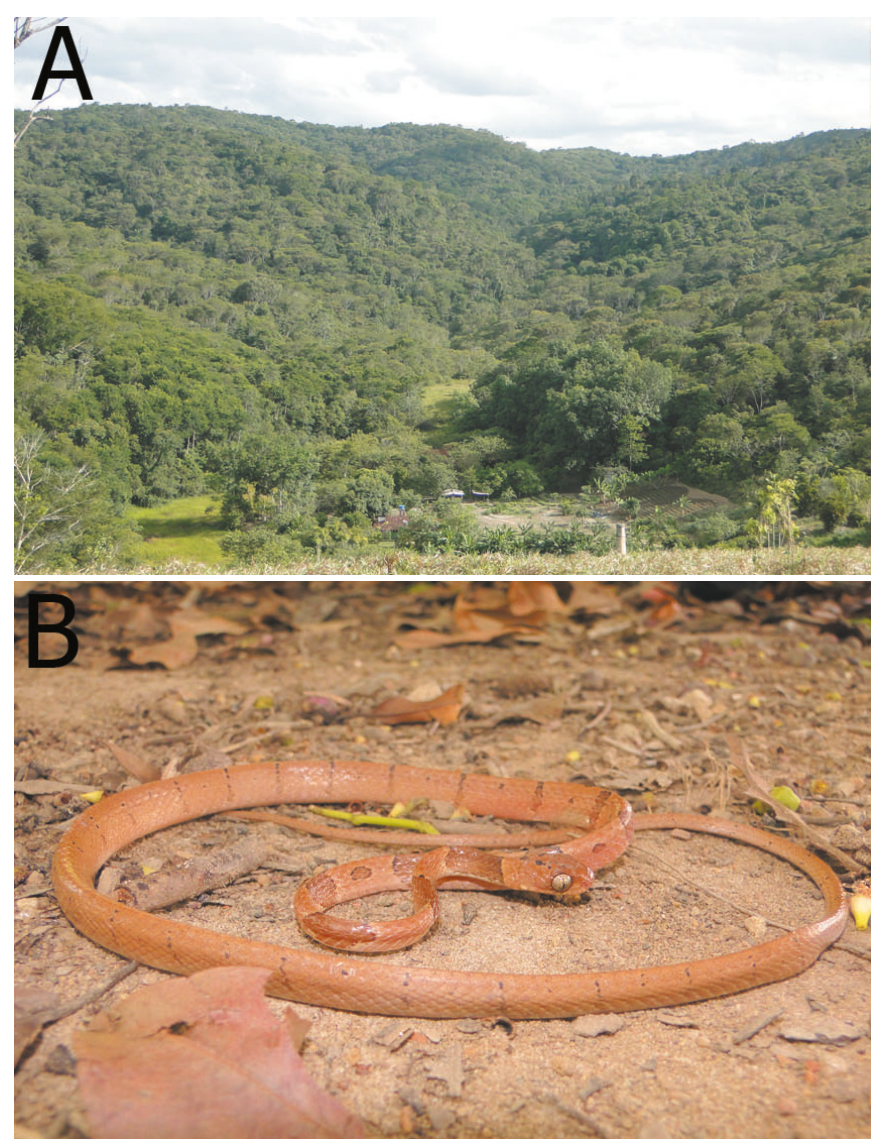

Figure 3. A) View of the RPPN Pedra D'Antas, municipalities of Lagoa dos Gatos and Jaqueira, State of Pernambuco, Brazil. B) Adult individual of Dipsas sazimai (URCA H-5097), from the municipality of Jaqueira, state of Pernambuco, Brazil. Photos by Igor J. Roberto 
and molecular data could help in identify whether these populations are different or represent clinal variation.

Dipsas sazimai is the rarest species within the Dipsas genus in the Atlantic Forest domain and considered potentially threatened (Fernandes et al. 2010). The discovery of this new population of D. sazimai highlights the conservation importance of the Serra do Urubu mountain range. Conservation actions in the Atlantic Forest, north to the São Francisco River, such as the creation of a Biodiversity corridor and/or measures to reconnect and restore the forest remnants are badly needed to allow recolonization and reestablishment of the gene flow among animal populations (Asfora and Pontes 2009).

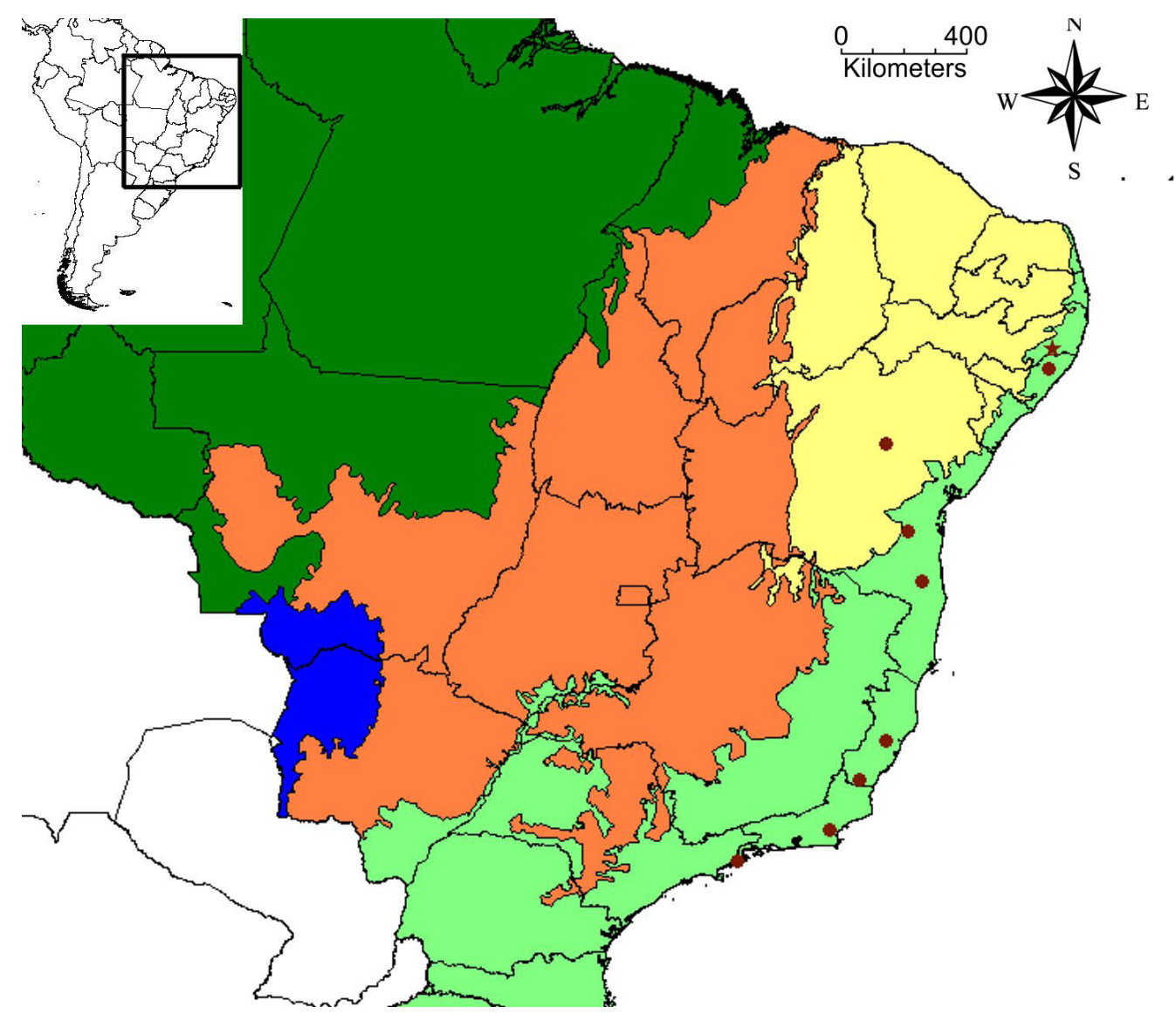

FIGURE 2. Geographic distribution map of Dipsas sazimai in Brazil. Red points are those from Fernandes et al. (2010) and the star represents the new record.

ACKNOWLEDGMENTS: We thank SAVE for providing permits to work at the RPPN Pedra D'Antas and for the conservation actions realized in the Serra do Urubu mountain range. José Antônio Vicente Filho for providing accommodation, field assistance and conservation efforts at RPPN Pedra D’Anta. To Fundação Cearense de Apoio ao Desenvolvimento Científico e Tecnológico - FUNCAP for master fellowship to Igor J. Roberto and for a research grant awarded to Robson W. Ávila (BPI-0067-00006.01.00/12). To ICMBIO for collecting permits (No. 34734-1).

\section{Literature Cited}

Asfora, P.H. and A.R.M. Pontes. 2009. The small mammals of the highly impacted North-eastern Atlantic Forest of Brazil, Pernambuco Endemism Center. Biota Neotropica 9(1): 31-35.

Fernandes, D.S., O.A.V. Marques and A.J.S. Argôlo. 2010. A new species of Dipsas Laurenti from the Atlantic Forest of Brazil. Zootaxa 2691(4): 57-66.

Hamdan, B., and R.M. Lira-da-Silva. 2012. The snakes of Bahia State, northeastern Brazil: species richness, composition and biogeographical notes. Salamandra 48(1): 31-50.
Ribeiro, M.C., J.P. Metzger, A.C. Martensen, F.J. Ponzoni and M.M. Hirota. 2009. The Brazilian Atlantic Forest: how much is left, and how is the remaining forest is distributed? Implications for conservation. Biological Conservation 142(6): 1142-1153.

Silva, J.M.C. and C.H.M. Casteleti. 2003. Status of the biodiversity of the Atlantic Forest of Brazil pp. 43-59, in: C. Galindo-Leal and I. G. Câmara (ed.). The Atlantic Forest of South America: biodiversity status, threats, and outlook. Washington: CABS \& Island Press.

Tabarelli, M., J.A. Siqueira Filhoand A.A. Santos. 2005. Floresta Atlântica ao norte do Rio São Francisco; pp. 25-40, in: K.C. Porto, J.S. AlmeidaCortez and M. Tabarelli (org). Diversidade Biológica e Conservação da Floresta Atlântica ao norte do Rio São Francisco. Ministério do Meio Ambiente. Brasília. Brasil.

RECEIVED: April 2013

ACCEPTED: December 2013

Published ONLINE: February 2014

EDITORIAL RESPONSIBILITY: Pedro Henrique Bernardo 